\title{
Nové pohledy na P. J. Šafař́ka
}

\author{
Miloš Zelenka (České Budějovice)
}

Pavol Jozef Šafárik v kontinuite. Eds. Marianna Sedláková - Marián Gladiš. Košice: Filozofická fakulta Univerzity Pavla Jozefa Šafárika v Košiciach, 2017. 192 s. ISBN 978-80-8152-564-3.

Monograficky koncipovaná publikace, na níž se převážně podíleli pracovníci Katedry slovakistiky, slovanských filológií a komunikácie na FF UPJŠ v Košicích, zahrnula příspěvky ze dvou seminářů (v letech 2012 a 2015) věnovaných této významné vědecké i umělecké osobnosti a zároveň důstojně navázala na předchozí šafaříkovské sborníky a akce z let 1993 a 1995. Editoři celkem šestnáct studií s úvodním slovem rozdělili do dvou kompozičně i myšlenkově symetrických bloků: interdisciplinárního a literárněvědného. Jestliže první část má kulturologický a heuristický charakter, druhá řeší teoreticko-metodologické problémy týkající se konkrétních interpretací a také otevírá aktuální okruhy přesahující do genologie, sémiotiky či srovnávacího myšlení. V záplavě textů české literární historiografie (K. J. Paul, J. Novotný, F. Wollman, S. Wollman ad.), slovenské (J. Sabol, P. Káša, J. Gbúr, F. Štraus ad.), ale i středoevropské (polské, německé) a ruské, tato publikace ukazuje na skutečnost, že stále existují „bílá místa“ v šafaříkovském bádání, resp. že nosné plochy tohoto výzkumu směřují $\mathrm{k}$ hlubšímu syntetizujícímu a interdisciplinárnímu pohledu na dílo, které stálo u zrodu novodobého chápání slovanské filologie.

V interdisciplinární části se po úvodním slovu editorů připomínají důležitá data $\mathrm{z}$ dějin šafaříkovského zkoumání na filozofických fakultách v Prešově a Košicích (J. Dudášová), autorovy politické aktivity zejména spjaté s revolučním rokem 1848 (M. Gbúrová). Materiálově podchycenou dokumentaci vztahů P. J. Šafaříka $\mathrm{s}$ J. Kollárem a M. Hamuljakem přináší znamenitá stat A. Matovčíka, obdobně L. Bartko hodnotí práce slovenského lingvisty Štefana Tóbika zabývající se jazykem P. J. Šafaříka, resp. jeho rozdělením slovenských nářečí např. v konfrontaci se štúrovskou tradicí. K charakteristice a funkci jednotlivých překladů Slovanských starožitnosti do slovanských i neslovanských jazyků se vrací příspěvek I. Ripky. Po publicisticky laděném textu J. Darma (v podstatě načrtávajícím Šafaříkův podíl na genezi etnicity Slováků) následuje zajímavý referát L. Tajtáka mapující recepční ohlas Slovanských starožitností v mad’arském vědeckém kontextu, zejména u A. Vámbéryho. Didaktický aspekt uplatňuje M. Sedláková, která podnětně upozorňuje na studijní potenciál některých badatelových textů při výuce národní filologie.

Literárněvědný blok otevírá stručnější, ale obsahově hutná úvaha o preromantismu ve slovenské literatuře v souvislosti s iniciačním impulsem P. J. Šafař́ka (J. S. Sabol). Zde jen doplnění, že v současnosti se nejen romantická prefáze a postfáze i ve svých národních podobách, jak doložil svazek World Literature Studies (2011, č. 1-2) věnovaný teoretické reflexi evropského romantismu a preromantismu, chápe jako heterogenní „rizomatická struktura“, žánrově oscilující a realizující se v jakýchsi paprskovitých „vlnách“, což zpochybňuje tento pojem poprvé definovaný u P. van Tieghema jako chronologického a hodnotového přechodu mezi klasicismem a preromantismem. Zasvěcený teoreticko-versologický rozbor Šafaříkových názorů na časomíru, zejména však na sylabotónickou prozódii v souvislosti s Počátky českého básnictví..., obsahuje společná studie J. Gbúra a J. Sabola. Do oblasti binární komparatistiky zasahuje příspěvek P. Káši srovnávající myšlenkovou motiviku i poetologickou strukturu P. J. Šafaříka a A. Mickiewicze. O diferenciaci mimetické a imaginativní linie lyrického subjektu v Šafař́ikově poezii se pokouší text J. Součka, který 
aplikuje známou tezi o konstantní oscilaci mezi fantastickým a racionálním principem v literárním vývoji. U sbírky Tatranská múza s lýrou slovanskou L. Cifraničová analyzuje prostřednictvím uchopení motivu přírody již dostatečně reflektovaný Šafaříkův přechod od klasicistní poetiky k romantickému ideálu harmonie. Konstituování kulturního typu národního slovenského hrdiny, v podstatě jánošíkovského mýtu v básníkových textech, sleduje P. Getlík, který v souladu se slovenskou literární historiografií vidí ve folklorních inspiracích preromantické impulsy. Obdobně Jánošíkův mýtus v básni Posledni noc interpretuje na pozadí filozoficko-antropologického modelu lásky M. Marcinčin. Publikaci poté uzavírá translatologický prríspěvek M. Andričíka, který přesvědčivě traktuje Feldekovo přebásnění Tatranské múzy s lýrou slovanskou jako specifický typ intralingválního překladu.
Publikace celkově dokumentuje fakt, že heuristicky a ani interpretačně není Šafaříkovo básnické a vědecké dílo uzavřeno. Je škoda, že osobnost Šafař́ḱk se vytratila z badatelského pohledu bohemistiky, což nesvědčí v její prospěch, uvědomíme-li si, jakou pozornost Šafaříkovu (a také Kollárovu) dílu věnovala pozitivistická generace Vlčkova a Jakubcova, a to v souvislosti s otázkou jinonárodních vlivů, zejména německých, na domácí obrození. Lze jen proto ocenit, že pro slovakistické pracoviště v Košicích není Šafařík jen povinná „pracovní náplň“, ale reálný předmět zájmu i mladší vědecké generace. Publikace, která nově reinterpretuje množství tradičních témat, jako např. oscilaci klasicismu a preromantických impulsů v básníkových textech či jeho názory na etnicitu a genezi Slovanů, tvoří hodnotově rovnocenný pendant ke stále probíhajícímu vydávání Spisov Pavla Jozefa Šafárika.

\section{Prof. PhDr. Miloš Zelenka, DrSc.}

Katedra slovanských jazyků a literatur

Pedagogická fakulta, Jihočeská univerzita

Jeronýmova 10, 37115 České Budějovice, Česká republika

zelenka@pf.jcu.cz 